Scientia Marina 71(3)

September 2007, 579-591, Barcelona (Spain)

ISSN: 0214-8358

\title{
Interactions between shorebirds and benthic invertebrates at Culbin Sands lagoon, NE Scotland: Effects of avian predation on their prey community density and structure
}

\author{
VANDA MARIYAM MENDONÇA ${ }^{1,2}$, DAVID GEORGE RAFFAELLI ${ }^{3}$ \\ and PETER R. BOYLE ${ }^{4}$ \\ ${ }^{1}$ Centre of Marine Sciences (CCMAR) / Centre of Marine and Environmental Research (CIMAR), University of Algarve, \\ Gambelas 8000 Faro, Portugal. \\ ${ }^{2}$ P.O. BOX 3013, Seeb 111, Oman. E-mail: drvandamendonca@yahoo.com \\ ${ }^{3}$ Department of Environment, University of York, YO 105DD, UK. \\ ${ }^{4}$ Department of Zoology, University of Aberdeen, AB24 2TZ, UK.
}

SUMMARY: In the North Sea, during autumn-winter, intertidal flats often receive a massive influx of migratory shorebirds (wildfowl, waders and seabirds), which utilise the high prey densities that are available. The present study was conducted at Culbin Sands lagoon, NE Scotland, in 1994-1996, to investigate benthic invertebrate standing stock, and the energy flow from benthic invertebrates to shorebirds. Benthic invertebrate standing stock was estimated to be $500 \mathrm{~kJ} \mathrm{~m}^{-2} \mathrm{yr}^{-1}$, and shorebird consumption efficiency to be $18 \%$ of the available standing stock. A series of manipulative field experiments were then conducted to test the effects of shorebirds on benthic invertebrate densities and community structure. Birds were excluded from caged areas (exclosures), and benthic invertebrate densities (total and by class size) in caged and uncaged areas were compared for each season separately. During autumn-winter, especially the gastropod Hydrobia ulvae and larger-sized $(>15$ $\mathrm{mm}$ ) clams Macoma balthica were observed to be the most impacted species, being significantly more abundant in birdexclosures than in bird-accessed areas.

Keywords: shorebirds, invertebrates, prey-size selection, Culbin lagoon.

RESUMEN: EFECTOS DE LA DEPREDACIÓN POR AVES EN LA DENSIDAD Y ESTRUCTURA DE LACOMUNIDAD DE PRESAS. - En el mar del Norte, durante otoño-invierno, las llanuras intermareales sufren la afluencia masiva de aves migratorias (anátidas, limícolas y aves marinas) que utilizan las elevadas densidades de presas disponibles. El presente estudio fue llevado a cabo en la laguna de Culbin Sands, en el noreste de Escocia, durante los años 1994 a 1996 a fin de investigar la biomasa de invertebrados marinos y el flujo de energía desde los invertebrados bentónicos a las aves costeras. La biomasa de invertebrados bentónicos fue estimada en $500 \mathrm{~kJ} \mathrm{~m}^{-2} \mathrm{yr}^{-1}$, y la eficiencia de consumo por parte de las aves costeras como el 18\% de la biomasa disponible. Una serie de experimentos de campo manipulativos fue llevada a cabo para determinar los efectos de las aves costeras sobre las densidades de invertebrados bentónicos y sobre la estructura de la comunidad. Las aves fueron excluidas de áreas cerradas a su acceso. Las densidades de invertebrados bentónicos (totales y por clase de talla) en áreas cerradas y abiertas a su acceso fueron comparadas por separado para cada estación del año. En otoño-invierno, el gasterópod Hydrobia ulvae y ejemplares de gran talla (>15 mm) del bivalvo Macoma balthica fueron las especies que sufrieron un mayor impacto, siendo significativamente más abundantes en zonas cerradas que en zonas abiertas al acceso de las aves.

Palabras clave: aves costeras, invertebrados, selección de presas por talla, laguna de Culbin. 


\section{INTRODUCTION}

Sheltered coastal areas are often characterised by high benthic invertebrate production, and often support complex food webs, especially in estuaries, fjords and lagoons. On less exposed shores, the range of predators is greatly expanded compared with that on more exposed sediment coasts and on rocky shores, to include also large numbers of highly mobile forms, notably epibenthic crustaceans such as shrimps (e.g. brown shrimp Crangon crangon), crabs (e.g. shorecrab Carcinus maenas), fish such as gobies (e.g. common goby Pomatoschistus microps) and juvenile flatfish (e.g. plaice Pleuronectes platessa and flounder Platichthys flesus) (e.g. Evans, 1983). These areas are also very important feeding grounds for shorebirds. The term 'shorebird' refers to birds which have any activity such as resting, feeding or nesting within the shore system (Baird et al., 1985). This term covers not just waders (Scolopacidae) but also wildfowl (Anatidae), gulls (Laridae), terns (Sterninae) and other aquatic birds that regularly use coastal habitats. Many of these species obtain a substantial proportion of their daily energy requirements, if not all of them, from intertidal areas. Therefore, where these birds occur in high densities, the impact of their predation pressure on the ecology of the intertidal zone might be considerable. For instance, Goss-Custard (1980), using direct observation, estimated that on shores around the British coast waders took between 25 and $45 \%$ of the autumn standing crops of their prey over the subsequent winter. Many other studies, based on indirect methods, estimated the consumption efficiency of shorebirds based on bird abundance, predation rates and energetic requirements. Some of these studies are presented in Table 1.
Although estimates of the energy flowing from prey to predators are important to understand an ecosystem and the consumption efficiency of a predator or group of predators, they might not reflect the real functional implications of a trophic link. For example, Paine (1980) showed that the most important functional link in a rocky shore community had little energy flowing along it. Also, many predators only consume parts of their prey, and their effects are often not lethal. Therefore, the least equivocal way to determine whether prey are significantly affected by predators is to carry out manipulative experiments or to observe a natural experiment. Moreover, energy flow and manipulative field experiments should be seen as complementary rather than alternative approaches to the study of the shore as a system.

According to Raffaelli and Milne (1987), impacts of birds on their prey communities are best assessed by manipulative experiments in which prey densities are compared between areas where birds have access (uncaged) and areas where birds are excluded (caged). This approach has been extensively applied in the Ythan estuary, Scotland, on an intertidal flat, where despite the high values of consumption efficiency by birds (Table 1), results showed no significant effects of bird predation pressure on benthic invertebrate communities, either on areas outside mussel beds (Raffaelli and Milne, 1987) or on mussel bed areas (Raffaelli et al., 1990).

Culbin Sands lagoon, in the Moray Firth, NE Scotland, is a small lagoon $3 \mathrm{~km}$ long and $1 \mathrm{~km}$ wide, whose intertidal area is used by a relatively dense community of shorebirds (Table 2) feeding on benthic invertebrates, especially during autumn and winter. Although bird densities may not be as great

TABLE 1. - Consumption by birds (estimated as invertebrate production/ removal by birds) at several intertidal areas in W Europe.

\begin{tabular}{lccc}
\hline Intertidal flat & $\begin{array}{c}\text { Consumption by birds } \\
\left(\mathrm{kJ} \mathrm{m}^{-2} \mathrm{yr}^{-1}\right)\end{array}$ & $\begin{array}{c}\text { Consumption efficiency } \\
(\%)\end{array}$ & REFERENCE(S) \\
\hline $\begin{array}{l}\text { Grevelin Estuary, } \\
\text { The Netherlands (NW Europe) }\end{array}$ & 71.5 & 6 & Wolff and de Wolff, 1977 \\
$\begin{array}{l}\text { Wadden Sea, } \\
\text { The Netherlands (NW Europe) }\end{array}$ & 103.6 & 17 & Evans et al., 1984 \\
$\begin{array}{l}\text { Tees Estuary, } \\
\text { England, UK (NW Europe) }\end{array}$ & 367.0 & 44 & Baird et al., 1984 \\
$\begin{array}{l}\text { Ythan Estuary, } \\
\text { Scotland, UK (NW Europe) }\end{array}$ & 873.6 & 37 & Moreira, 1997 \\
$\begin{array}{l}\text { Tagus Estuary, } \\
\text { Portugal (SW Europe) }\end{array}$ & 103.0 & 12 & \\
\hline
\end{tabular}


TABLE 2. - Wintering birds at several intertidal areas in NW Europe.

\begin{tabular}{|c|c|c|c|c|c|c|c|c|c|c|c|}
\hline & $\begin{array}{l}\text { Total area } \\
\text { References } \\
\text { Bird density }\end{array}$ & \multicolumn{2}{|c|}{$\begin{array}{c}\text { Dutch Grevelin } \\
\text { Estuary } \\
140 \mathrm{~km}^{2} \\
\text { Wolff and de Wollf,1977 } \\
\text { ind. } \mathrm{yr}^{-1} \quad \text { ind. } \mathrm{km}^{-2}\end{array}$} & \multicolumn{2}{|c|}{$\begin{array}{c}\text { Dutch } \\
\text { Wadden Sea } \\
1300 \mathrm{~km}^{2} \\
\text { Evans et al.,1985 } \\
\text { ind. } \mathrm{yr}^{-1} \quad \text { ind. } \mathrm{km}^{-2}\end{array}$} & \multicolumn{2}{|c|}{$\begin{array}{l}\text { Tee Estuary, UK } \\
\qquad 17.5 \mathrm{~km}^{2} \\
\text { Evans et al., } 1985 \\
\text { ind. } \mathrm{yr}^{-1} \text { ind. } \mathrm{km}^{-2}\end{array}$} & \multicolumn{2}{|c|}{$\begin{array}{l}\text { Ythan Estuary, } \\
\text { UK } \\
2.4 \mathrm{~km}^{2} \\
\text { Raffaelli et al., } 1990 \\
\text { ind. } \mathrm{yr}^{-1} \quad \text { ind. } \mathrm{km}^{-2}\end{array}$} & \multicolumn{2}{|c|}{$\begin{array}{l}\text { Culbin Lagoon, } \\
\text { UK } \\
3 \mathrm{~km}^{2} \\
\text { Hancock, } 1993 \\
\text { ind. } \mathrm{yr}^{-1} \text { ind. } \mathrm{km}^{-2}\end{array}$} \\
\hline \multicolumn{12}{|c|}{ Anatidae (wildfowl) } \\
\hline Merganser & Mergus serrator & 0 & 0 & 3900 & 3.00 & 0 & 0 & 0 & 0 & 11 & 3.66 \\
\hline Mallard & Anas platyrhyncus & 0 & 0 & 0 & 0 & 0 & 0 & 0 & 0 & 36 & 12.00 \\
\hline Wigeon & Anas penelope & 0 & 0 & 0 & 0 & 0 & 0 & 0 & 0 & 276 & 92.00 \\
\hline Greylag Goose & Anser anser & 0 & 0 & 0 & 0 & 0 & 0 & 0 & 0 & 2 & 0.66 \\
\hline Shelduck & Tadorna tadorna & 578 & 4.12 & 21000 & 16.15 & 161 & 9.20 & 50 & 20.83 & 74 & 24.66 \\
\hline Longtailed duck & Clangula hymalis & 0 & 0 & 0 & 0 & 0 & 0 & 0 & 0 & 2 & 0.66 \\
\hline Eider & Somateria molissima & 0 & 0 & 62000 & 47.69 & 0 & 0 & 500 & 208.33 & 10 & 3.33 \\
\hline Goldeneye & Bucephala clangula & 0 & 0 & 1800 & 1.38 & 0 & 0 & 0 & 0 & 4 & 1.33 \\
\hline \multicolumn{12}{|c|}{ Scolopacidae (waders) } \\
\hline Oystercatcher & Haematopus ostralegus & 16430 & 117.35 & 120000 & 92.30 & 0 & 0 & 400 & 166.66 & 1219 & 406.33 \\
\hline Knot & Calidris canutus & 2610 & 18.64 & 50000 & 38.46 & 0 & 0 & 60 & 25.00 & 1065 & 355.00 \\
\hline Sanderling & Calidris alba & 0 & 0 & 0 & 0 & 0 & 0 & 0 & 0 & 65 & 21.66 \\
\hline Dunlin & Calidris alpina & 6602 & 47.15 & 12000 & 9.20 & 0 & 0 & 400 & 166.66 & 1138 & 379.33 \\
\hline Curlew & Numenius arquata & 2085 & 14.89 & 150 & 0.11 & 0 & 0 & 150 & 62.50 & 230 & 76.66 \\
\hline Redshank & Tringa totanus & 559 & 3.99 & 10000 & 7.69 & 0 & 0 & 500 & 208.33 & 514 & 171.33 \\
\hline Turnstone & Arenaria interpres & 337 & 2.40 & 2000 & 1.53 & 0 & 0 & 80 & 33.33 & 3 & 1.00 \\
\hline Bar-tailed Godwit & Limosa lapponica & 805 & 5.75 & 30000 & 23.07 & 0 & 0 & 40 & 16.66 & 880 & 293.33 \\
\hline Grey Plover & Pluvialis squatarola & 567 & 4.05 & 5600 & 4.30 & 0 & 0 & 0 & 0 & 49 & 16.33 \\
\hline Ringed Plover & Charadrius hiaticula & 0 & 0 & 1100 & 0.84 & 0 & 0 & 30 & 12.50 & 33 & 11.00 \\
\hline \multicolumn{12}{|c|}{ Laridae (gulls) } \\
\hline Gulls & Unspecified & 4026 & 28.75 & 120000 & 92.30 & 0 & 0 & 0 & 0 & 0 & 0 \\
\hline
\end{tabular}

at Culbin as in some other reported areas, the impact of predation by birds on the invertebrate communities may still be significant. The availability (standing stock) of prey species (benthic invertebrates) for shorebirds at Culbin Sands lagoon was studied from February 1994 to August 1996, and the energy flow from benthic invertebrates to shorebirds was investigated. Effects of shorebirds on benthic macrofauna densities and community structure were assessed through a series of manipulative experiments (caged areas as predator-exclosures; and uncaged areas as controls) conducted throughout the period 19951996, divided into three seasons: autumn-early winter (October 1995-December 1995); winter-early spring (December 1995-April 1996) and summer (June 1996-September 1996).

\section{METHODS}

\section{The study area: Culbin Sands lagoon}

The Moray Firth includes many areas of conservation importance classified as either National Nature Reserves (NNR) or Sites of Special Scientific Interest (SSSI). Culbin Sands area, on the southern shores of the Moray Firth and east of the Loch Ness, includes three bars (Nairn; Culbin; and New Bars) that are a result of the breaching, three centuries ago, of a single bar across the mouth of the river Findhorn. Together they now represent the largest sand dune system in Britain with 3180 ha in area (Tilbrook, 1986). Between 1922 and 1931 the Culbin Bar area enclosing the Culbin Sands lagoon was acquired by the Forestry Commission, who decided to stabilize the sand dunes through plantation, successfully completed in the late 1960s. Culbin Sands area (including a forested area of 28 ha and a bared sand dune enclosing a lagoon with 1.5 ha of intertidal flats) was then notified as an SSSI in July 1973, and re-notified in 1981, under the Wildlife and Countryside Act.

The macrotidal Culbin Sands lagoon has a permanently submersed gully with a maximum depth of $2.5 \mathrm{~m}$ at high tide; closer to the mouth of the main gully, the sediment is coarser and poorer in silt content (Hanssen, 1993). The lagoon is a relatively undisturbed system, as it has been isolated from human disturbance for most of the last century, although in June 1995 and during the course of this study there was an unprecedented and unexpected event of cockle harvesting using tractor and mechanical rakes, after which access to the lagoon was once more restricted by a gated road, and permission from the authorities is now required. 
Published scientific literature on Culbin Sands includes studies on its geology (Tilbrook, 1986; Pollard and McLennan, 1992), bird population (Campbell et al., 1986; Mudge, 1986; Hancock, 1993), plankton (Adams and Martin, 1986), and commercially valuable molluscs and fish species (Hopkins, 1986). Unpublished available literature includes reports to the Nature Conservancy Council (Wells and Boyle, 1975; Bartrop et. al., 1980) and reports by the University of Aberdeen (Hanssen, 1993, van Schie, 1993, Mendonça, 1997).

\section{Energy flow from benthic invertebrates to shorebirds}

In order to estimate the benthic invertebrate standing stock at Culbin Sands lagoon, NE Scotland, benthic communities were studied from February 1994 to August 1996 at three sites, selected on intertidal areas near the main gully. The sites did not differ much in terms of sediment characteristics (median particle sizes of up to $120 \mu \mathrm{m}$ for sites 1 and 3, and $130-140 \mu \mathrm{m}$ for Site 2, and silt contents of $0-5 \%$ for all three sites; Hanssen, 1993; van Schie, 1993), but because differences in the hydrodynamic characteristics of the sites could impact the benthic communities, they were selected according to distance to the bar: Site 1 was in sheltered areas west of the bar; Site 2 closer to the bar; and Site 3 in sheltered areas east of the bar, but closer to the mouth of the gully than Site 1 (Fig. 1).

In February 1994, a pilot survey was conducted to determine the minimum amount of samples which represented the benthic invertebrate macrofauna $(>500 \mu \mathrm{m})$ species density and diversity with $95 \%$ confidence interval. During this survey, 10 cores (of $11 \mathrm{~cm}$ diameter equivalent to $100 \mathrm{~cm}^{2}$ area) were collected per site, showing that for most species six cores was the minimum number of samples to be collected. Exceptions were species with patchy distribution. Mytilus edulis mussel beds were not studied, although they occupy about $18000 \mathrm{~m}^{2}$ at Culbin Sands (Mendonça, 1997). Semibalanus sp. were attached to dead shells and especially abundant on the poles erected during World War II as glider defences, more specifically at the levels reached by the high tide, and this species was also not sampled.

Following the conclusions of the pilot survey, six cores were then collected per site every 2-4 weeks, from May 1994 to August 1996. Samples were collected at low tide, to a sediment depth of $15 \mathrm{~cm}$,

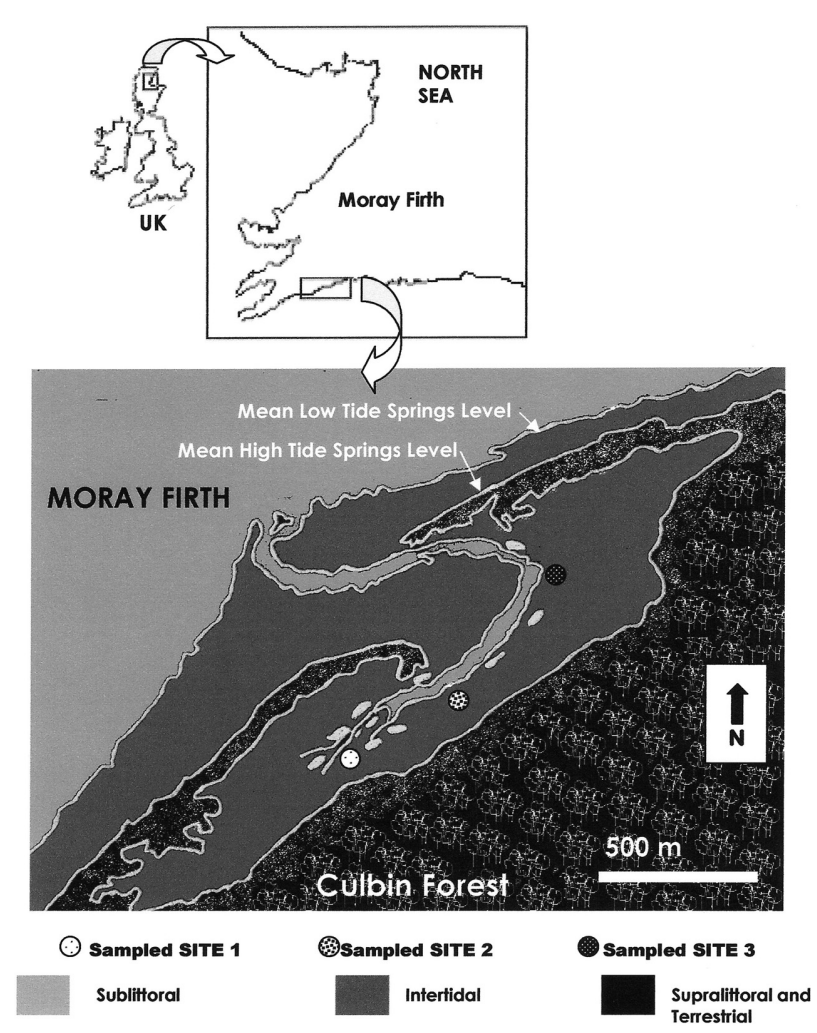

FIG. 1. - Culbin Sands in the southern part of the Moray Firth, NE Scotland, with indication of the three sites sampled to estimate benthic invertebrates standing stock. Site 1 was also where manipulative field experiments were conducted to study avian effects on benthic invertebrate communities. Lighter patches on the intertidal near the main gull represent mussel beds.

from within a randomly placed $1 \mathrm{~m}^{2}$ quadrat (Raffaelli and Hawkins, 1996). Samples were subsequently sieved over a $500 \mu \mathrm{m}$ mesh and preserved in alcohol $(70 \%)$ till identification.

Core sampling was inefficient for large species such as lugworms Arenicola marina and Carcinus maenas crabs. Therefore, lugworm densities were estimated only in winter (February 1995 and February 1996) and summer (July 1995 and August 1996), by counting the number of casts in 10 quadrats of $0.5 \mathrm{~m} \times 0.5 \mathrm{~m}$ randomly placed at each site. Crab densities were sampled monthly at the three sites. As densities were very low on the intertdal flat, a push-net $(0.5 \mathrm{~m}$ wide) was used along a 50-m-long transect in the main gully, to a depth of up to $0.5 \mathrm{~m}$. All results were converted into ind. $\mathrm{m}^{-2}$.

Standing stock or mean biomass (gAFDW $\mathrm{m}^{-2}$ $\mathrm{yr}^{-1}$ ) was estimated for each species based on mean numbers for 1994-1995 and 1995-1996 and the mean individual ash-free dry weight (AFDW). AFDW was obtained from dry weight (DW) for each species using the conversion factors (Table 3). The mean individual DW was obtained from 30 individuals 
TABLE 3. - Conversion factors for deriving AFDW from DW, and energy content $\left(\mathrm{J} \mathrm{mg}^{-1}\right)$ in benthic invertebrate macrofauna $(>500 \mu \mathrm{m})$. ASFD is ash free dry weight; DW is dry weight. $1 \mathrm{~J}=0.239 \mathrm{cal} ; 1 \mathrm{cal}=4.187 \mathrm{~J} ; 12 \mathrm{kcal}=1 \mathrm{gC}$ (McNeill and Lawton, 1970).

\begin{tabular}{llll}
\hline TAXA & Size class $(\mu \mathrm{m})$ & $\begin{array}{c}\text { Conversion factor from DW } \\
\text { to AFDW (Rumhor } \text { et al., 1987) }\end{array}$ & $\begin{array}{l}\text { Conversion factor from weight to energy } \\
\text { energy content J mg-1 (weight type; reference) }\end{array}$ \\
\hline Nemerteans & $<1000$ & 0.70 & 23.40 (DW; Ankar and Elmgreen, 1976) \\
Nematodes & $<1000$ & 0.70 & 23.40 (DW; Ankar and Elmgreen, 1976) \\
& $\geq 1000$ & 0.30 & $\begin{array}{l}23.09 \text { (AFDW; Brey } \text { et al., 1988) } \\
\text { Oligochaetes: 22.36 (DW; Brey et al., 1988) }\end{array}$ \\
Annelids & $<1000$ & 0.70 & Polychaetes: 23.33 (AFDW; Brey et al., 1988) \\
& $\geq 1000$ & 0.30 & 22.40 (AFDW; Brey et al., 1988) \\
Arthropod/Crustaceans & $<1000$ & 0.70 & 22.40 (AFDW; Brey et al., 1988) \\
& $\geq 1000$ & 0.30 & Chironomids: 23.81 (AFDW; Brey et al., 1988) \\
Arthropod/ Insects & $<1000$ & 0.70 & Chironomids: 23.81 (AFDW; Brey et al., 1988) \\
& $\geq 1000$ & 0.30 & 23.27 (AFDW; Brey et al., 1988) \\
Molluscs/Gastropods & $<1000$ & 0.10 & 23.27 (AFDW; Brey et al., 1988) \\
& $\geq 1000$ & 0.15 & 22.79 (AFDW; Brey et al., 1988) \\
Molluscs/Bivalves & $<1000$ & 0.10 & 22.79 (AFDW; Brey et al., 1988)
\end{tabular}

selected randomly from each size class considered. Individuals in samples were separated into size classes where possible. Maximum length was measured to the nearest millimetre and the individuals were divided into two classes, $<1000 \mu \mathrm{m}$ and $\leq 1000 \mu \mathrm{m}$, with the exception of bivalves in which maximum width was measured and they were divided into five classes: 500-1000, 1000-1500, 1500-2000, 2000-3000 and $>3000 \mu \mathrm{m}$. For species with a shell (bivalves and gastropods) the shell-free dry weight (SFDW) was estimated. Gastropods (mostly Hydrobia ulvae) were not easily dissected from the shell because of their small size, so flesh dry weigh (FDW) was estimated as $27 \%$ of the total dry weight, after the studies of Boyle and Raffaelli (1981) and Raffaelli and Boyle (1986) in Nigg Bay, also in the Moray Firth, NE Scotland, although flesh weight shows some degree of variation throughout the year. All material was dried to constant weight $\left(70^{\circ} \mathrm{C} ; 24 \mathrm{~h}\right.$; in the incinerator). Biomass values in $\mathrm{g}$ were converted into $\mathrm{J}$ using conversion factors (also in Table 3).

The flow from benthic invertebrates to shorebirds for the whole Culbin Sands lagoon, NE Scotland, in terms of both biomass (gAFDW $\mathrm{m}^{-2} \mathrm{yr}^{-1}$ ) and energy $\left(\mathrm{kJ} \mathrm{m}^{-2} \mathrm{yr}^{-1}\right)$, was estimated based on bird densities (Table 2) and energetic requirements for these birds in NW Europe. A general daily ingestion rate of 30\% of individual body weight was assumed, although many factors such as age, sex, season, time of day and reproduction cycle phase contribute to variations in body mass, metabolic rates, ingestion rates, and energy requirements of birds even within the same species, as there is a relationship between body size, metabolism and ingestion rate (e.g. Furness, 1978; Cramp and Simmons, 1983; Feltham and Davies, 1996; Kelly et al., 2002a, 2002b). Individual body weight for each species was selected from the lower values of the range, as these were more representative of the situation at the beginning of autumn-winter.

\section{Manipulative field experiments to test avian impact on benthic invertebrates}

The energy flow studies were complemented by manipulative field experiments to test effects of birds on their prey communities. Previous experiments have shown that caging experiments were more likely to succeed where the sediment is more stable and currents less strong (Reise, 1978). Therefore, away from the mouth of the gully, Site 1 was selected to deploy the caging experiments (Fig. 1). Caging experiments were not carried out on mussel bed areas of Mytilus edulis, as at Culbin lagoon shorebirds were rarely seen feeding on mussel beds.

Two types of exclosure were used: a set of six exclosures for all predators (shorebirds and mobile epibenthic fauna such as fish and crustaceans) were used to provide information on predator effects for the period October 1995-December 1995 and December 1995-April 1996; and a set of six exclosures for birds only were used to test effects of birds for the period June 1996-September 1996. Cages were dispersed randomly over the intertidal area. All 
cages were $1 \mathrm{~m} \times 1 \mathrm{~m}$ in area, and $30 \mathrm{~cm}$ high. The first set was a metal frame covered by $2 \mathrm{~mm}$ mesh and depressed $15 \mathrm{~cm}$ into the sediment; the second set had the same dimensions but consisted simply of stakes placed $1 \mathrm{~m}$ from each other, with strings wound round them $15 \mathrm{~cm}$ apart to a height of $30 \mathrm{~cm}$ and roofing also created with strings, as used by Raffaelli and Milne (1987). The experiments were monitored weekly during the low tide period to remove any drifting weed or other material, which collected on the cages. For the second set of experiments, bird footprints and some peck marks were found outside but never inside the bird exclosures, showing that despite the low cost and simple design, the cages were efficient.

In order to investigate effects of shorebirds on their prey, at the end of each of the three seasons considered in this study, six core samples of $11 \mathrm{~cm}$ in diameter were randomly taken from the sediment to a depth of $15 \mathrm{~cm}$ from each cage. For the second set of cages, sediment sampling avoided the area within $10 \mathrm{~cm}$ of the perimeter of the cage, just in case birds had gained access to it. For each season, six similar cores were taken randomly from the whole uncaged area surrounding the cages, in order to search for depletion of benthic invertebrates caused by birds. Core samples were sieved through a $1 \mathrm{~mm}$ mesh, since invertebrates smaller than $1 \mathrm{~mm}$ are not likely to be bird prey items. Benthic invertebrates were preserved in alcohol $(70 \%)$ until identification and separation into size classes.

In order to determine whether there were any caging artefacts, during the seasons October 1995December 1995 and December 1995-April 1996 three smaller cores ( $7 \mathrm{~cm}$ diameter, $10 \mathrm{~cm}$ depth) of sediment per treatment (from caged and uncaged areas) were collected for silt content studies. For the season June 1996-September 1996 caging effects on silt content were not studied as previous experiments by Raffaelli and Milne (1987) showed that the relatively large open area of these exclosures cause no artefacts. For silt content analysis, samples were dried to constant weight $\left(70^{\circ} \mathrm{C}, 24 \mathrm{~h}\right.$; in incinerator), wet sieved through a $63 \mu \mathrm{m}$ mesh, and dried again to constant weight to provide the percentage of silt (Holme and McIntyre, 1984). Percentages of silt content in the sediment between the treatments were compared by t-test or U-test depending on the dataset characteristics (e.g. Sokal and Rohlf, 1995). Due to the large number of tests carried out, a high significance level was considered $(\mathrm{P}<0.01)$ to avoid
Type I errors. Also, to avoid potential problems of pseudoreplication (Hurlbert, 1984), the data of all samples from the same cage (for both invertebrate densities and silt content) were pooled to provide a single value for each cage.

The data on benthic invertebrates in sediment samples from these experiments were used to conduct two other tests: effects of shorebirds on the benthic invertebrate community density throughout the year; and effects of shorebirds on the benthic invertebrate community structure throughout the year.

To test the effects of shorebirds on the benthic invertebrate density, absolute frequencies of each species were compared between the treatments (caged and uncaged for each of the considered seasons) by ANOVA. Given the number of tests conducted, Sequential Bonferroni Tests with $\alpha=0.05$ were carried out to find the critical $\mathrm{P}$ (probability) level of significance (Sokal and Rohlf, 1995).

To test predator size selection by shorebirds, relative frequencies by size-class of prey species (after arc-sin transformation; Zar, 1996) were compared between caged and uncaged areas by ANOVA, and Sequential Bonferroni Tests with $\alpha=0.05$ were used to find the critical $\mathrm{P}$ level of significance.

Comparisons of individuals by size class were only possible for the most abundant species (Hydrobia ulvae, Cerastoderma edule and Macoma balthica) due to restricted size range encountered for other species, which were all about the same size.

\section{RESULTS}

\section{Energy flow from benthic invertebrates to shorebirds}

At Culbin Sands lagoon, NE Scotland, the overall standing stock of benthic invertebrates during the period 1994-1996 was estimated at $500 \mathrm{~kJ} \mathrm{~m}^{-2} \mathrm{yr}^{-1}$ or $26 \mathrm{gAFDW} \mathrm{m}^{-2} \mathrm{yr}^{-1}$ (Fig. 2). The biggest contributors to the standing stock values were the lugworm polychaete Arenicola marina and the cockle bivalve Cerastoderma edule. The overall annual consumption by birds was estimated at $18 \%$ of the available benthic invertebrate prey standing stock, and is equivalent to $90 \mathrm{~kJ} \mathrm{~m}^{-2} \mathrm{yr}^{-1}$ or $5.98 \mathrm{gAFDW} \mathrm{m}^{-2} \mathrm{yr}^{-1}$.

Mean density and standing stock values at the three sampled sites by individual species are presented respectively in Table 4 and Table 5. 


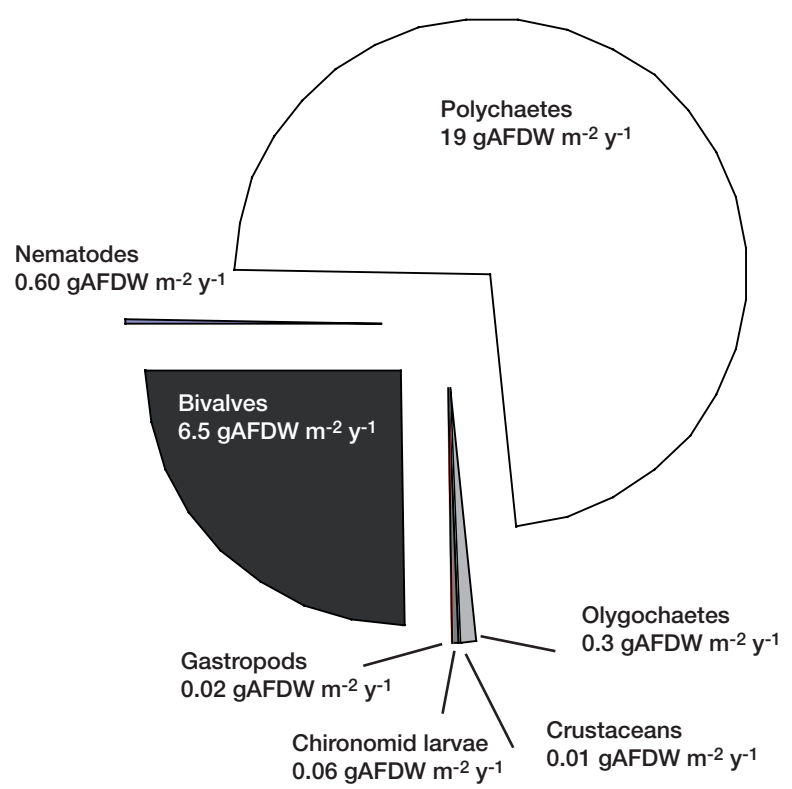

FIG. 2. - Overall standing stock ( $\mathrm{gAFDW} \mathrm{m}^{-2} \mathrm{yr}^{-1}$ ) of benthic macroinvertebrates at Culbin Sands lagoon, NE Scotland, during the period 1994-1996. Values correspond to areas outside mussel bed areas, with Arenicola marina contributing 95\% of the total stock of polychaetes, and Cerastoderma edule contributing $85 \%$ of the total stock of bivalves.

\section{Manipulative field experiments to test avian impact on benthic invertebrates}

As the silt content in sediment samples was not significantly different between caged and uncaged areas, and also between the two seasons in which net-type cages were used (i.e. between the October 1995-December 1995 and the December 1995April 1996 experiments; $\mathrm{P}>0.05$ in all cases: $\mathrm{t} / \mathrm{U}$ test), it was concluded that there were no caging artefacts.

Benthic invertebrate densities in sediment samples from both caged (exclosures) and uncaged areas (bird-accessed areas) for all seasons showed no significant differences in densities of larger polychaete species such as Phyllodoce mucosa, Pygosio elegans, and Scoloplos armiger although there was some degree of depletion in uncaged areas for Pygospio elegans (Fig. 3). Effects of shorebirds on densities of other larger polychaetes such as Polydora ciliata were not analysed as this polychaete species was present in low densities in sam-

TABLE 4. - Mean density (ind. $\mathrm{m}^{-2}$ ) of individuals of most abundant invertebrate species during the periods 1994-1995 and 1995-1996 at the three sampled sites at Culbin Sands, NE Scotland. Infaunal species not listed showed an overall mean $<2$ ind. $\mathrm{m}^{-2}$; crabs showed overall abundance $\leq 0.2$ ind. $\mathrm{m}^{-2}$.

\begin{tabular}{|c|c|c|c|c|c|c|}
\hline $\begin{array}{l}\text { Year } \\
\text { Site }\end{array}$ & 1 & $\begin{array}{c}94-19 \\
2\end{array}$ & 3 & 1 & $\begin{array}{c}1995-1996 \\
2\end{array}$ & 3 \\
\hline Nemerteans & 1710 & 388 & 684 & 3210 & 342 & 342 \\
\hline Nematodes & 300 & 80 & 250 & 350 & 75 & 280 \\
\hline \multicolumn{7}{|l|}{ Annelids/Polychaetes } \\
\hline Arenicola marina & 55 & 53 & 54 & 50 & 50 & 52 \\
\hline Capitella capitata & 289 & 26 & 236 & 500 & 131 & 218 \\
\hline Fabricia sabella & 9 & 4 & 52 & 4 & 13 & 5 \\
\hline Nereis diversicolor & 5 & 5 & 13 & 4 & 4 & 6 \\
\hline Nephthys hombergii & 0 & 5 & 15 & 0 & 5 & 10 \\
\hline Ophelia rathkei & 0 & 25 & 30 & 0 & 5 & 10 \\
\hline Phyllodoce тисова & 66 & 52 & 66 & 53 & 13 & 50 \\
\hline Polydora ciliata & 13 & 13 & 13 & 4 & 4 & 13 \\
\hline Pygospio elegans & 26 & 26 & 52 & 105 & 131 & 79 \\
\hline Scoloplos armiger & 54 & 30 & 13 & 53 & 4 & 26 \\
\hline Travisia forbesi & 3 & 3 & 4 & 4 & 4 & 4 \\
\hline \multicolumn{7}{|l|}{ Annelids/Oligochaetes } \\
\hline Tubificoides benedini & 3000 & 421 & 1342 & 2315 & 263 & 315 \\
\hline Arthropods/Crustaceans & & & & & & \\
\hline Bathyporeia pilosa & 5 & 210 & 131 & 6 & 157 & 13 \\
\hline Corophium volutator & 5 & 0 & 0 & 10 & 0 & 0 \\
\hline Eurydice pulchra & 0 & 0 & 5 & 0 & 0 & 4 \\
\hline \multicolumn{7}{|l|}{ Arthropods/Insects } \\
\hline Chironomid larvae & 290 & 13 & 150 & 13 & 3 & 26 \\
\hline \multicolumn{7}{|l|}{ Molluscs/Gastropods } \\
\hline Hydrobia ulvae & 10 & 0 & 0 & 6 & 0 & 0 \\
\hline Littorina littorea & 13 & 10 & 10 & 13 & 6 & 6 \\
\hline Retusa obtusa & & & & & & \\
\hline \multicolumn{7}{|l|}{ Molluscs/Bivalves } \\
\hline Cerastoderma edule & 105 & 79 & 158 & 131 & 79 & 140 \\
\hline Macoma balthica & 79 & 26 & 52 & 53 & 26 & 52 \\
\hline Mya arenaria & 3 & 0 & 0 & 2 & 0 & 0 \\
\hline Tellina tenuis & 13 & 5 & 5 & 13 & 5 & 6 \\
\hline Total (ind. $\mathrm{m}^{-2}$ ) & 6173 & 1559 & 3583 & 7046 & 1403 & 1803 \\
\hline
\end{tabular}


TABLE 5. - Mean standing biomass ( $\mathrm{gAFDW} \mathrm{m}^{-2}$ ) of individuals of most abundant invertebrate species during the periods 1994-1995 and 1995-1996 at the three sampled sites at Culbin Sands, NE Scotland. Based on densities (Table 4) and mean individual weight for species (using $\mathrm{N}=30$ ind. per species and size class). Infaunal species not listed showed an overall mean $<2$ ind. $\mathrm{m}^{-2}$. Crabs Carcinus maenas (epibenthic) showed overall abundance $\leq 0.2$ ind. $\mathrm{m}^{-2}$.

\begin{tabular}{|c|c|c|c|c|c|c|}
\hline $\begin{array}{l}\text { Yer } \\
\text { Site }\end{array}$ & 1 & $\begin{array}{c}994-199 \\
2\end{array}$ & 3 & 1 & $\begin{array}{c}1995-1996 \\
2\end{array}$ & 3 \\
\hline Nematodes & 0.075 & 0.021 & 0.060 & 0.093 & 0.022 & 0.071 \\
\hline \multicolumn{7}{|l|}{ Annelids/Polychaetes } \\
\hline Arenicola marina & 19.327 & 18.662 & 18.924 & 17.532 & 17.556 & 18.571 \\
\hline Capitella capitata & 0.0820 & 0.007 & 0.060 & 0.143 & 0.036 & 0.063 \\
\hline Fabricia sabella & 0.001 & 0.001 & 0.01 & $<0.001$ & 0.003 & 0.001 \\
\hline Nereis diversicolor & 0.022 & 0.020 & 0.046 & 0.014 & 0.014 & 0.021 \\
\hline Nephthys hombergii & 0 & 0.012 & 0.044 & 0 & 0.012 & 0.035 \\
\hline Ophelia rathkei & 0 & 0.008 & 0.012 & 0 & 0.002 & 0.005 \\
\hline Phyllodoce тисова & 0.050 & 0.037 & 0.052 & 0.037 & 0.009 & 0.035 \\
\hline Polydora ciliata & 0.045 & 0.045 & 0.045 & 0.014 & 0.014 & 0.045 \\
\hline Pygospio elegans & 0.091 & 0.091 & 0.272 & 0.225 & 0.271 & 0.170 \\
\hline Scoloplos armiger & 0.323 & 0.170 & 0.074 & 0.323 & 0.227 & 0.145 \\
\hline \multirow{2}{*}{\multicolumn{7}{|c|}{ Annelids/Oligochaetes }} \\
\hline & & & & & & \\
\hline $\begin{array}{l}\text { Tubificoides benedini } \\
\text { Arthropods/Crustaceans }\end{array}$ & 0.842 & 0.061 & 0.190 & 0.642 & 0.092 & 0.115 \\
\hline Bathyporeia pilosa & $<0.001$ & 0.026 & 0.008 & $<0.001$ & 0.022 & 0.002 \\
\hline Corophium volutator & $<0.001$ & 0 & 0 & $<0.001$ & 0 & 0 \\
\hline Eurydice pulchra & 0 & 0 & $<0.001$ & 0 & 0 & $<0.001$ \\
\hline \multicolumn{7}{|l|}{ Arthropods/Insects } \\
\hline Chironomid larvae & 0.231 & 0.005 & 0.020 & 0.005 & 0.002 & 0.012 \\
\hline \multicolumn{7}{|l|}{ Molluscs/Gastropods } \\
\hline Hydrobia ulvae & 0.001 & 0 & 0 & $<0.001$ & 0 & 0 \\
\hline Littorina littorea & 0.016 & 0.015 & 0.012 & 0.016 & 0.008 & 0.008 \\
\hline Retusa obtusa & 0.012 & 0.003 & 0.006 & $<0.001$ & $<0.001$ & $<0.001$ \\
\hline \multicolumn{7}{|l|}{ Molluscs/Bivalves } \\
\hline Cerastoderma edule & 6.385 & 5.014 & 10.625 & 2.325 & 1.375 & 3.370 \\
\hline Macoma balthica & 2.379 & 0.782 & 1.560 & 1.591 & 0.786 & 1.562 \\
\hline Mya arenaria & 0.631 & 0 & 0 & 0.427 & 0 & 0 \\
\hline Tellina tenuis & 0.133 & 0.051 & 0.050 & 0.133 & 0.055 & 0.069 \\
\hline Total (gAFDW m²) & 30.64 & 25.03 & 32.01 & 23.52 & 20.50 & 24.29 \\
\hline Total $\left(\mathrm{kJ} \mathrm{m}^{-2}\right)$ & 702 & 576 & 740 & 541 & 472 & 559 \\
\hline
\end{tabular}

ples throughout the year, making it difficult to compare results between caged and uncaged areas.

For the gastropod Hydrobia ulvae there were significant differences in densities between caged and uncaged areas throughout the year, but this was not observed for other gastropod species such as Littorina spp. or Retusa obtusa. (Fig. 4).

The density of bivalves Macoma balthica also showed significant differences between caged and uncaged areas, with higher densities in caged areas (bird exclosures) during autumn-winter and winterspring (Fig. 5).

For those species having significant differences between caged and uncaged areas, the same samples which provided the above results were analysed again, but this time after separating into size classes, and revealed the following results (Fig. 6):

- For gastropods Hydrobia ulvae, only the proportion of individuals of size class $>3 \mathrm{~mm}$ was less abundant in bird-accessed areas during summer ( $\mathrm{P}$ significant, ANOVA, Bonferroni); and size class 2-3 $\mathrm{mm}$ also showed some degree of depletion from bird-accessed areas during summer ( $P$ just above level of significance, ANOVA, Bonferroni);

- For cockles Cerastoderma edule, only size class $>15 \mathrm{~mm}$ showed some degree of depletion in bird accessed areas during autumn-winter ( $\mathrm{P}$ just above level of significance), and was significantly less abundant in bird-accessed areas in winter-spring ( $\mathrm{P}$ significant); and

- For clams Macoma balthica, size class > $>15 \mathrm{~mm}$ was less abundant in bird accessed areas all year round ( $\mathrm{P}$ just above level of significance during autumn-winter, and $\mathrm{P}$ significant during the rest of the year), and size class 5-15 mm also showed some degree of depletion from bird-accessed areas during winter-spring ( $\mathrm{P}$ just above level of significance).

This procedure could not be applied to the polychaete Pygospio elegans because specimens were all about the same size. 

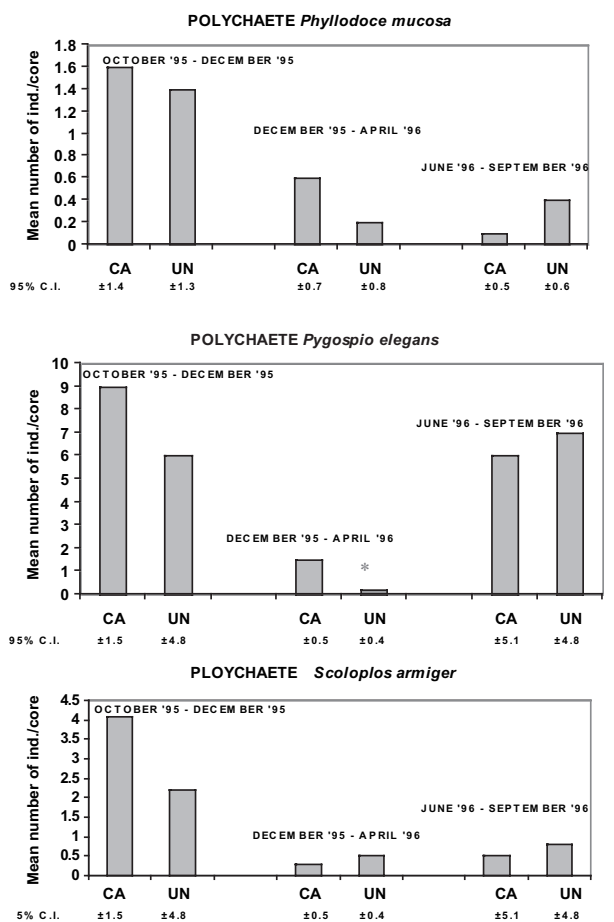

FIG. 3. - Testing the effects of shorebirds on benthic invertebrate $(>1 \mathrm{~mm})$ community density: absolute frequency of polychaetes (Phyllodoce mucosa, Pygospio elegans, and Scoloplos armiger) in caged (CA) and uncaged (UN) areas over one year at Culbin Sands lagoon, NE Scotland (*differences just above the level of significance; tests: ANOVA, Bonferroni).

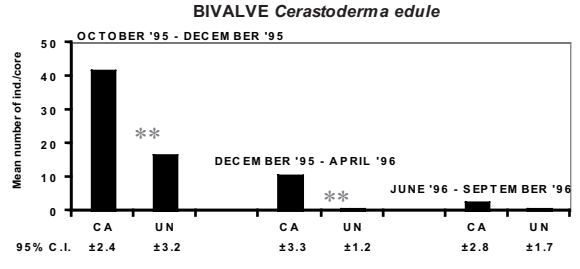

BIVALVE Macoma balthica
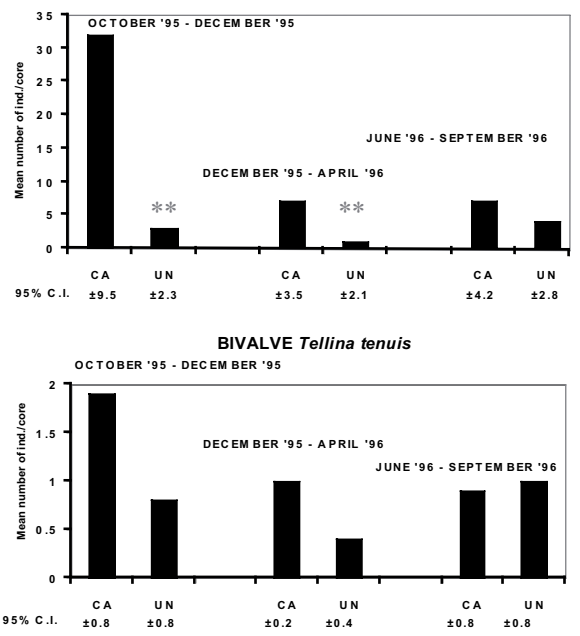

FIG. 5. - Testing the effects of shorebirds on benthic invertebrate $(>1 \mathrm{~mm})$ community density: absolute frequency of bivalves (Cerastoderma edule, Macoma balthica and Tellina tenuis) in caged (CA) and uncaged (UN) areas over one year at Culbin Sands lagoon, NE Scotland (** significant differences; * differences just above the level of significance; tests: ANOVA; Bonferroni).
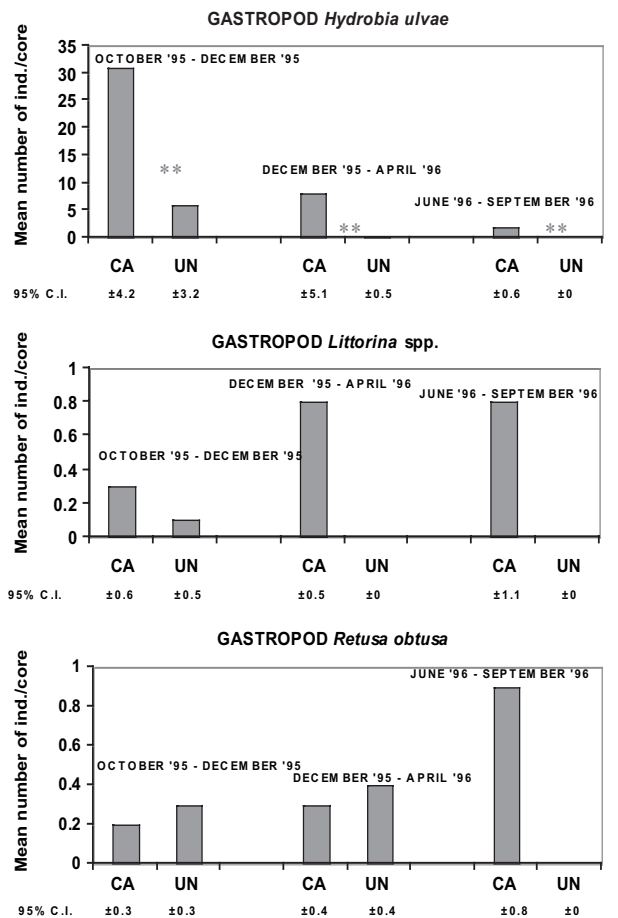

FIG. 4. - Testing the effects of shorebirds on benthic invertebrate $(>1 \mathrm{~mm})$ community density: absolute frequency of gastropods (Hydrobia ulvae, Littorina spp. and Retusa obtusa) in caged (CA) and uncaged (UN) areas over one year at Culbin Sands lagoon, NE Scotland (** significant differences; tests: ANOVA, Bonferroni).
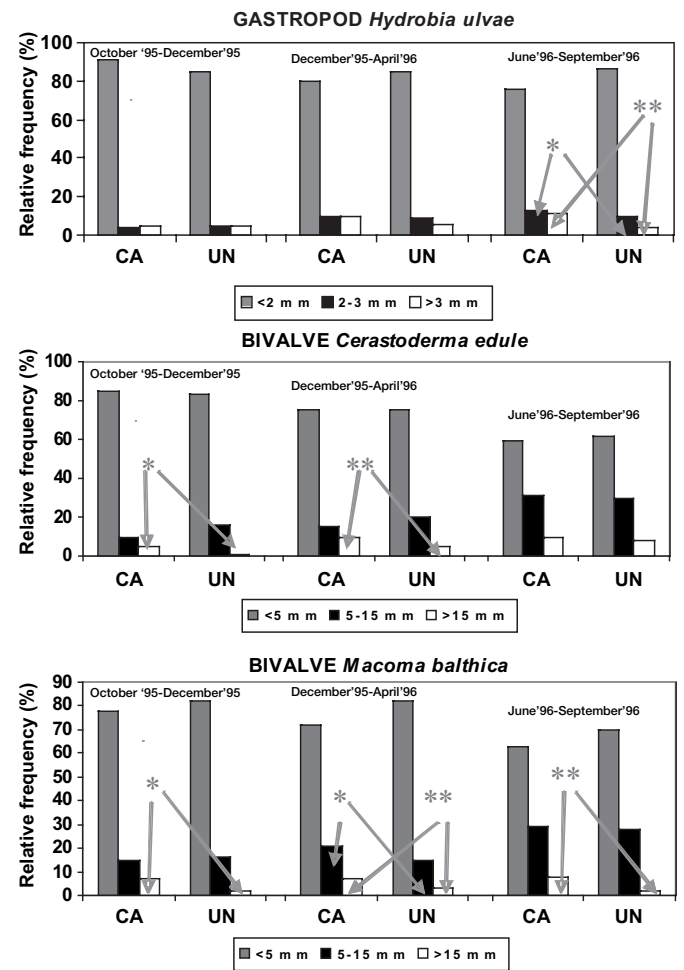

FIG. 6. - Testing the effects of shorebirds on benthic invertebrate $(>1 \mathrm{~mm})$ community structure: relative frequency of the three sizeclasses of Hydrobia ulvae, Cerastoderma edule and Macoma balthica in caged (CA) and uncaged (UN) areas over one year at Culbin Sands lagoon, NE Scotland (** significant differences; * differences just above the level of significance; tests: ANOVA, Bonferroni). 


\section{DISCUSSION}

\section{Energy flow from benthic invertebrates to shorebirds}

Differences in standing stock of benthic invertebrates at Culbin Sands from 1994-1995 to 19951996, which showed a reduction of $22 \%$, could have been due to natural variations, or most likely the consequence of the unexpected and unprecedented event of cockle harvesting which took place in June 1995. Harvesting by tractor affected the topography of the shore (Mendonça, 1997) and bivalves broken during the harvesting and left to decompose at the site probably contributed (at least temporarily) to anoxic conditions in the sediment, negatively affecting benthic macrofauna (e.g. Diaz and Rosenberg, 1995). Nevertheless, after the event there was no indication of shorebird population decline at Culbin Sands.

When the results obtained in the present study are compared with those obtained for other areas (e.g. Ythan estuary - Baird et al., 1985; Dutch Wadden Sea - Boaden and Seed, 1985; and those listed in Table 1, although those estimates were in terms of removal from the annual production while in this study the data were in terms of removal from the standing stock), it may nevertheless be concluded that the study area could even support a larger population of shorebirds, as the consumption efficiency by the shorebird population in other areas was generally greater than that estimated for Culbin Sands lagoon. However, the efficiency value is likely to be greater if one considers only the standing stock of larger individual prey, which is likely to be selected by shorebirds.

\section{Manipulative field experiments to test avian impact on benthic invertebrates}

As inferred from the manipulative field experiments conducted in this study, during autumn-winter and winter-spring, when both birds and epibenthic predators (e.g. shrimps, crabs and fish) were excluded, there were no significant differences in benthic invertebrate prey densities between exclosures (caged areas) and controls (uncaged areas) for most benthic invertebrate infaunal species. Exceptions were only for larger mollusc species Hydrobia ulvae, Cerastoderm edulea, and Macoma balthica. These differences were significant in both periods, but they could not have been due to the presence of the epibenthic predators such as shrimps and fish because these prey sizes were too large to be taken by those predators (e.g. Becker and Chew, 1987). Additionally, epibenthic predators feed on bivalve siphon parts, which are anyway easily regenerated (e.g. Sandberg et al., 1996). Moreover, if epibenthic predators had any significant effects on their prey, then it would be most obvious at this time of year, because they also have their recruitment in summer in areas of the North Sea (e.g. Evans, 1983; Mendonça, 1997), but since there were no demonstrable effects of epibenthic predators, it seems that the differences between predator exclosures (caged areas) and controls (uncaged areas) were due to the presence of shorebirds only. In fact, larger molluscs are likely prey for shorebirds such as knot Calidris canutus, dunlin Calidris alpina, redshank Tringa tetanus and bar-tailed godwit Limosa lapponica (all abundant in autumn-winter at Culbin) and shelduck Tadorna tadorna, (which was still being observed at Culbin in summer). Another wildfowl species abundant at Culbin is the wigeon Anas Penelope, but this is a herbivore species (e.g. Heinzel et al., 1995). Some bird species such as the oystercatcher Haematopus ostralegus, especially abundant at Culbin, are known to specialise in larger bivalves in the Wadden Sea, preferring older cockles Cerastoderma edule, adult Macoma balthica, and juvenile Mya arenaria (e.g. Beukema and Cadee, 1996). Selection of larger prey by birds has also been observed in the Delaware Bay, USA (Bottom et al., 1994; Andres, 2003; STC, 2003). As well as having direct impacts on their prey, shorebird predation pressure may also have indirect effects on other epibenthic predators, by reducing the available prey for juvenile fish and shrimps. In addition, shorebirds physically disturb the sediment during feeding activity, and the combined effects of predation and disturbance may be considerable (e.g. Bonsdorff et al., 1995).

At Culbin Sands, many invertebrate species, especially bivalves, showed a peak of recruitment during the period September-November, just before the arrival of the massive influx of birds. This may reduce the overall effects of birds on the bivalve community. The occurrence of the bivalve recruitment in autumn at Culbin Sands was obvious from the tremendous increase in numbers of small bivalves found in caged areas, although the 
presence of cages could also have produced exaggerated differences in numbers of small bivalves between caged and uncaged areas, as conditions in caged areas may favour settlement of larvae. However, cage artefacts seem unlikely because there were no differences in silt content between the caged and uncaged areas. Least likely but also possible, higher numbers of small bivalves as well as of small Hydrobia ulvae in caged areas during the periods October 1995-December 1995 and December 1995-April 1996 may also be associated with the macroalgal mats growing in caged areas, although they were cleaned every week. Macroalgae and other biogenic structures seem to promote higher numbers of infaunal species, until a point is reached where weed turns the sediment anoxic and populations start to decline (e.g. Yates et al., 1996). Some authors (e.g. Turpie and Hockey, 1997) even relate shorebirds and weed mats, perhaps because shorebirds know that benthic invertebrates are probably more abundant in these areas. However, the depletion of Hydrobia ulvae from uncaged areas in summer (June 1996September 1996) when string-type cages were used were most likely due to predatory pressure by shorebirds, which are still present during summer. Also, densities in caged areas during the summer experiment could be increased due to horizontal migration of benthic invertebrate species from uncaged to caged areas. However, with significantly lower densities of larger molluscs in uncaged areas also during autumn (October 1995-December 1995) and winter (December 1995-April 1996), it seems that differences between caged and uncaged areas in summer were most likely due to the presence of some birds which were over-wintering at these habitats and predated on larger molluscs (e.g. Burger et al., 1997). Finally, as the proportion of small molluscs (Hydrobia and bivalves) was not significantly different between caged and uncaged areas, the number of small molluscs in caged areas may simply indicate mollusc production, when effects of both epibenthic predators and birds are totally removed.

The results from the caging experiments also showed that differences in densities between caged and uncaged areas were more significant for Macoma balthica than for Cerastoderma edule. In fact, Piersma et al. (1993), and Kube et al. (1996) claim that the bivalve Macoma balthica is the preferred food for waders in the Wadden Sea, with Hydrobia ulvae,
Mytilus edulis and Cerastoderma edule being eaten when Macoma balthica becomes less abundant. In fact, several authors (e.g. Zwarts et al., 1994; Piersma et al., 2003) have observed that Macoma balthica has several advantages from the point of view of these predators: they have a high biomass/volume ratio; they are not excessively wide in comparison with the predator's beak width; they do not live too deep in the sediment; their shell is not as hard to break as that of other species such as Cerastoderma edule; and they are relatively abundant.

However, Prater (1981) and Wanink and Zwarts (2001) found that shorebirds also have a preference for larger polychaetes Arenicola marina, Nereis sp. and Nepthys hombergii. These polychaete species were abundantly present at Culbin, but probably because larger-sized molluscs (especially Macoma balthica but also Cerastoderma edule) were also abundantly available, shorebirds concentrated more on predating on molluscan prey, as consuming larger-sized prey is energetically more profitable and particular size ranges of each prey species are frequently favoured according to their profitability (Kalejta, 1993). The energetics and cost benefits of shorebirds feeding preferably on molluscs have been analysed by several authors (e.g. Wanink and Zwarts, 2001; Gills et al., 2003, 2006a, 2006b; Rogers et al., 2006), who concluded that the availability of molluscs as prey for shorebirds may even determine shorebird distribution and abundance.

Other bivalve species such as Tellina tenuis and Mya arenaria seemed to be non-preferred bivalve species, probably because Tellina tenuis was relatively small in body size compared with Macoma balthica, whilst Mya arenaria was probably too large for most bird species predating at Culbin Sands lagoon.

Despite controversy regarding the use of manipulative field experiments, the tests conducted throughout the year at Culbin Sands, NE Scotland, showed significant differences in densities of gastropods and bivalves between caged and uncaged areas, reflecting a negative effect by shorebird predation pressure on both prey community density and structure. Consequently, shorebirds at Culbin Sands had a marked impact not only on the relative composition of the invertebrate communities, but also on the population structure of individual prey species such as Hydrobia ulvae, Cerastoderma edule and Macoma balthica. 


\section{ACKNOWLEDGEMENTS}

During this study, the first author was supported by the Ministry of Science, Technology and High Education of Portugal (PhD Research Fellowship Reference BD/CIENCIA/2593-IG, 25\% co-financed by the European Union Social Fund). We are also grateful for the logistics provided by the University of Aberdeen, and the collaboration of technicians (Mr. Chas Emes, Mr. Steve Hoskins, Mr. Robert Donaldson, Ms. Sue Way, and Mr. Charlie Thomson) and colleagues (Dr. Deborah Cha, Dr. Emillio Abelha, Ms. Huai Chang, and Dr. Stephen Ragnarsson). We gratefully appreciate the help provided by the authorities to access the study site and provide available unpublished reports. Our thanks especially to $\mathrm{Mr}$. David Law of the Scottish Natural Heritage / North East Region, Elgin, UK, and Mr. David O'Hara of the Royal Society for Protection of Birds, RSPB / North of Scotland Region, Inverness, UK.

\section{REFERENCES}

Adams, J.A. and J.H.A. Martin. - 1986. The hydrography and plankton on the Moray Firth. Proc. R. Soc. Edinb., 91B: 37-56.

Andres, B.A. - 2003. Delaware Bay shorebird-horseshoe crab assessment report: biological assessment. US Fish and Wildlife Service/Division of Migratory Bird Management, Airlington.

Ankar, S. and R. Elmgreen. - 1976. The benthic macro- and meiofauna of the Asko-Landsort area (northern Baltic proper). A stratified random sampling survey. Contrib. Asko Lab., 11: 1-115.

Baird, D., P.R. Evans, H. Milne and M.W. Pienkowski. - 1985. Utilization by shorebirds of benthic invertebrate production in intertidal areas. Oceanogr. Mar. Biol. Ann. Rev., 23: 573-597.

Bartrop, P.G., R. Bishop, N.A. Harvey, S.J.T. Holmes, Knight and H.T. Powell. - 1980. Survey of the littoral zone of the coast of Great Britain. Report to Nature Conservancy Council, no. 7.

Becker, D.S. and K.K. Chew. - 1987. Predation on Capitella spp. by small-mouthed pleuronectides in Puget Sound, Washington. Fish. Bull., 85: 471-479.

Beukema, J.J. and G.C. Cadee. - 1996. Consequences of the sudden removal of nearly all mussels and cockles from the Dutch Wadden Sea. Mar. Ecol., 17(1-3): 279-289.

Boaden, P.J.S. and R. Seed. - 1985. An introduction to coastal ecology. Chapman and Hall, New York.

Bonsdorff, E., A. Norkko and E. Sandberg. - 1995. Structuring zoobenthos: the importance of predation, cropping and physical disturbance. J. Exp. Mar. Biol.Ecol., 192: 125-144.

Bottom, M.L., R.E. Loveland and T.R. Jacobsen. - 1994. Size selection by migratory shorebirds in Delaware Bay, and its relationship to beach characteristics and abundance of horseshoe crab (Limulus polyphemus) eggs. Auk, 111(3): 605-616.

Boyle, P.R. and D.G. Raffaelli. - 1981. A survey of the marine intertidal invertebrates of Nigg and Udale Bays, Moray Firth, Scotland. The Beatrice Project environmental monitoring programme, Report to BNOC.

Brey, T., H. Rumohr and S. Ankar. - 1988. Energy content of macrobenthic invertebrates: general conversion factors from weight to energy. J. Exp. Mar. Biol. Ecol., 117: 271-278.

Burger, J., L. Niles and K.E. Clark. - 1997. Importance of beach, mudflat and marsh habitats to migrant shorebirds on Delaware Bay. Biol. Conserv., 79(2-3): 283-292.

Campbell, L.H., J. Barrett and C.F. Barrett. - 1986. Seaducks in the Moray Firth: a review of their current status and distribution.
Proc. Royal Soc. Edinb., 91B: 105-112.

Cramp, S. and K.E.L. Simmons. - 1983. Handbook of the birds of Europe, the Middle East and North Africa. The birds of Western Paleartic 3 - Waders to Gulls. Oxford University Press, Oxford.

Diaz, R.J. and R. Rosenberg. - 1995. Marine benthic hypoxia: a review of its ecological effects and the behavioural responses of the benthic macrofauna. Oceanogr. Mar. Biol. Ann. Rev., 33: 245-303.

Evans, S. - 1983. Epibenthic communities on shallow soft bottoms in Gullmar Fjord, Sweden. Ph. D. thesis, Uppsala.

Evans, P.R., J.D. Goss-Custard and W.G. Hale. - 1984. Coastal waders and wildfowl in winter. Cambridge Univ. Press, Cambridge.

Feltham, M.F. and F.M. Davies. - 1996. The daily food requirements of fish-eating birds: getting the sums right. In: P.R. Greenstreet and M.L. Tasker (eds), Aquatic Predators and Their Prey, pp. 53-57. Fishing News Books, Cambridge.

Furness, R.W. - 1978. Energy requirements of seabird communities: a bioenergetics model. J. Anim. Ecol., 47: 39-53.

van Gils, J.A., T. Piersma, A. Dekinga and M.-W. Dietz. - 2003. Cost-benefit analysis of mollusc-eating in a shorebird. II. Optimizing gizzard size in the face of seasonal demands. $J$. Exp. Biol., 206: 3369-3380.

van Gils, J.A., B. Spaans, A. Dekinga and T. Piersma. - 2006 a. Foraging in a tidally structured environment by red knots (Calidris canutus): ideal, but not free. Ecology, 87: 1189-1202.

van Gils, J.A., T. Piersma, A. Dekinga, B. Spaans and C. Kraan.$2006 \mathrm{~b}$. Shellfish dredging pushes a flexible avian top predator out of a marine protected area. PLoS Biol., 4(12): 376.

Goss-Custard, J.D. - 1980. Competition for food and interference among waders. Ardea, 68: 31-52.

Hancock, M. - 1993. Northern Firths Reserves: report on ornithological and wildfowl monitoring work - winter 1992-3. Royal Society for Protection of Birds.

Hanssen, S. - 1993. The intertidal macrofauna of Culbin, Moray Firth, Scotland. Eramus Project Report/Part I, University of Aberdeen, Aberdeen.

Heinzel, H., R. Fitter and J. Parslow. - 1995. Birds of Britain and Europe. Collins Pocket Guide, Norwich.

Holme, N.A. and A.D. McIntyre. - 1984. Methods for the study of marine benthos. Blackwell, Oxford.

Hopkins, P.J. - 1986. Exploited fish and shellfish species in the Moray Firth. Proc. R. Soc. Edinb., 91B: 57-72.

Hurlbert, S.H. - 1984. Pseudoreplication and design of ecological field experiments. Ecol. Monogr., 54(2): 187-211.

Kalejta, B. - 1993. Intense predation cannot always be detected experimentally - a case study of shorebird predation on nereid polychaetes in South Africa. Neth.J. Sea Res., 31(4): 385-393.

Kelly, J.P. and W.W. Weathers. - 2002a. Effects of feeding time constrains on body mass regulation and energy expenditure in wintering dunlin (Calidris alpina). Behav. Ecol., 13(6): 766-775.

Kelly, J.P., N. Warnock, G.W. Page and W.W. Weathers. - 2002b. Effects weather on daily body mass regulation in wintering dunlin. J. Exp. Mar. Biol. Ecol., 205: 109-120.

Kube, J., C. Peters and M. Powilleit. - 1996. Spatial variation in growth of Macoma balthica and Mya arenaria (Mollusca, Bivalvia) in relation to environmental gradients in the Pomeranian Bay (Southern Baltic Sea). Arch. Fish. Mar. Res., 44(1-2): 81-93.

McNeill, S. and J. H. Lawton. - 1970. Annual production and respiration in animal populations. Nature, 225: 472-474.

Mendonça, V. - 1997. Predator-prey interactions in a sandy shore system in the Moray Firth, NE Scotland. Ph. D. thesis, University of Aberdeen.

Moreira, F. - 1997. The importance of shorebirds to energy fluxes in a food web of a South European estuary. Estuar. Coast. Shelf Sci., 44(1): 67-78.

Mudge, G.P. - 1986. Trends of population change at colonies of cliff-nesting seabirds in the Moray Firth. Proc. Royal Soc. Edinb., 91B: 73-80.

Paine, R.T. - 1980. Food webs: linkage, interaction strength and community infrastructure. J. Anim. Ecol., 49: 667-685.

Piersma, T., R. Hoeksa, A. Dekinga, A. Koolhaas, A. Wolff, P. Batt and P. Wiersma. - 1993. Scale and intensity of intertidal habitat use by knots (calidris canutus) in the western Wadden Sea in relation to friends and foes. Neth. J. Sea Res., 31(4): 331-357. 
Piersma, T., A. Dekinga, J A van Gils, B. Achterkamp, and G.H. Visser. - 2003. Cost-benefit analysis of mollusc-eating in a shorebird. I. Foraging and processing costs estimated by the doubly labelled water method. J. Exp. Biol., 206: 3361-3368.

Pollard, M. and A. McLennan. - 1992. Management plan for Culbin Sands. Reserves Ecology. Royal Society for the Protection of Birds.

Prater, A.J. - 1981. Estuary birds of Britain and Ireland. T. and A. D. Poyser, Calton

Raffaelli, D. and P.R. Boyle. - 1986. The intertidal macrofauna of Nigg Bay. Proc. R. Soc. Edinb., 91B: 113-141.

Raffaelli, D. and H. Milne. - 1987. An experimental investigation of the effects of shorebird and flatfish predation on estuarine invertebrates. Estuar. Coast. Shelf Sci., 24: 1-13.

Raffaelli, D., V. Falcy and C. Galbraith. - 1990. Eider predation and the dynamics of mussel-beds communities. In: M. Barnes and R.N. Gibson (eds.), Trophic relationships in the marine environment, pp. 157-169. Proc. 24th Europ. Mar. Biol. Symp. Aberdeen University Press, Aberdeen.

Raffaelli, D. and S. Hawkins. - 1996. Intertidal ecology. Chapman and Hall, London.

Reise, K. - 1978. Predator exclusion experiments in an intertidal mudflat. Helgol. Wiss. Meeresunters. 30: 263-271.

Rogers, D., T. Piersma, and C. J. Hassell - 2006. Roost availability may constrain shorebird distribution: Exploring the energetic costs of roosting and disturbance around a tropical bay. Biol. Conserv., 133: 225-235.

Rumohr, H., T. Brey and S. Ankar. - 1987. A compilation of biometric conversion factors for benthic invertebrates of the Baltic Sea. Baltic Mar. Biol. 9: 1-56.

Sandberg, E., M. Tallqvist and E. Bonsdorff. - 1996. The effects of reduced oxygen content on predation and siphon cropping by the brown shrimp Crangon crangon. Mar. Ecol., 17(1-3): 411-423.

van Schie, A. - 1993. Marine intertidal invertebrate survey of Culbin Bar 1993. Erasmus Project Report/Part II, University of Aberdeen.
Sokal, R.R. and J.F. Rohlf. - 1995. Biometry. $2^{\text {nd }}$ ed. W. H. Freeman and Co., New York.

STC. - 2003. Delaware Bay shorebird-horseshoe crab assessment report and peer review. Report for the Atlantic States Marine Fisheries Commission/Shorebird Technical Committee, US Fish and Wildlife Service, Airlington.

Tilbrook, P.J. - 1986. Nature conservation in the Moray Firth. Proc. R. Soc. Edinb., 91B: 13-25.

Turpie, J.K. and P.A.R. Hockey. - 1997. Adaptive variation in the foraging behaviour of Grey Plover Pluvialis squatarola and whimbrel Numenius phaeopus. Ibis, 139(2): 289-298.

Wanink, J.H. and L. Zwarts. - 2001. Rate-maximizing optimality models predict when oystercatchers exploit a cohort of the bivalve Scrobicularia plana over a 7-year time span. J. Anim. Ecol., 70:150-158.

Wells, J.B. and P.R. Boyle. - 1975. Lock fleet littoral invertebrate survey. Report to the Nature Conservancy Council.

Wolff, W.J. and L. de Wolff. - 1977. Biomass and production of zoobenthos in the Grevelin estuary, The Netherlands. Estuar. Coast. Mar. Sci., 5: 1-24.

Yates, M.G., J.D. Goss-Custard, and W.E. Rispin. - 1996. Towards predicting the effect of loss of intertidal feeding areas on overwintering shorebirds (Charidrii) and shelduck (Tadorna tador$n a)$ : refinements and tests of a model developed for the Wash, East England. J. Appl. Ecol., 33(5): 944-954.

Zar, J.H. - 1996. Biostatistical analysis. 3rd ed. Prentice Hall Int. Ed., London.

Zwarts, L., A.M. Blomert, P. Spaak, and B. Devries. - 1994. Feeding radius, burying depth and siphon size of Macoma balthica and Scrobicularia plana. J. Exp. Mar. Biol. Ecol., 183(2): 193-212.

Scient. ed.: D. Oro.

Received November 6, 2006. Accepted May 15, 2007.

Published online July 13, 2007. 
